\title{
A study to evaluate the preservative action of Twak Arka in Triphala Kwatha
}

\author{
Research Article
}

\section{Rakshitha D1* ${ }^{*}$ Neha Semwal' ${ }^{1}$ Gazala Hussain²}

\author{
1. PG Scholar, 2. Assistant Professor, Department of Rasashastra and Bhaishajya Kalpana, \\ Sri Dharmasthala Manjunatheshwara College of Ayurveda \& Hospital, Hassan.
}

\begin{abstract}
Introduction: Primary dosage forms are basic preparations whose shelf life is a challenge for the practice. Kwatha is a preparation which is easily prone to contamination and can be marketed only by the addition of suitable preservatives to increase the shelf life. So addition of preservatives is being practiced to prolong the shelf life of kwatha but presently using chemical preservatives are harmful to body and even have carcinogenic effects. Hence there aroused a need to find natural preservatives. Arka which is a water distillate consists of essential substances from the crude drug and has longer shelf life. Twak arka possess anti- microbial and anti- oxidant properties and economically cheaper and easily available drug and triphala kwatha being useful in many purposes. In this study an attempt was made to elucidate the preservative action of twak arka in triphala kwatha. Materials and methods: Includes preparation of twak arka, triphala kwatha and conduction of analytical and microbiological study to see the preservative action using SDA and MHA media. Observations and results: Study follows observations over microbial growth of the sample on daily basis where twak arka showed preservative action for 31 days. Aspergillus niger was the fungal growth seen on 32nd day. Discussion: Twak arka owing to its $\mathrm{pH}$, chemical constituents and other properties preserved the triphala kwatha for a stipulated period of time. Conclusion: From the study, it was concluded that the twak arka preserved triphala kwatha without any microbial contamination for 31 days which was added in the concentration of $15 \%$.
\end{abstract}

Key Words: Twak arka, Triphala kwatha, Preservative, Microbiological study.

\section{Introduction}

Primary dosage forms are basic preparations whose shelf life is a challenge for their practice. In later days with the introduction of chemical preservatives, reuse of kwatha kalpana along with other primary dosage forms were emerged. Kwatha kalpana is one such which is more into clinical practice now-a-days. Kwatha is a preparation which is easily prone to contamination, possesses short shelf life of 24 hours or should be consumed immediately after its preparation and can be marketed only by the addition of suitable preservatives to increase the shelf life (1). Commonly used preservatives on long term usage they are proven to have carcinogenic and toxic effects over the body (2). So, there aroused a challenge to find a natural preservative.

Arka kalpana is a unique preparation explained by Ravana where through distillation method, essential oils from herbal drugs are extracted (3). This preparation is a product of distillation, do not undergo decomposition easily and stays for longer duration.

\section{* Corresponding Author:}

\section{Rakshitha D}

PG Scholar, Department of Rasashastra and

Bhaishajya Kalpana, Sri Dharmasthala

Manjunatheshwara College of Ayurveda \& Hospital,

Hassan- 573201. Karnataka. India

Email Id: rakshuammu2626@gmail.com
Twak (Cinnamomum zeylanicum Blume) belongs to Lauraceae family includes chemical constituents like cinnamaldehyde, eugenol, cumic aldehyde, cinnamyl alcohol, tannin, mucilage, etc. which are proven antimicrobial in nature (4). Useful part is bark which is aromatic, deodorant, diuretic, digestive, carminative, cardio tonic in nature. Triphala kwatha which is most commonly used kwatha possess many therapeutic actions and can be prepared by drugs which are easily available.

By considering all these points, to develop a natural preservative for kwatha kalpana, an attempt was made in this study to preserve triphala kwatha with arka of twak.

\section{Materials and Methods}

It is classified into following divisions

1. Preparation of twak arka

2. Preparation of triphala kwatha

3. Preparation of sample

4. Analytical study

5. Preparation of media

6. Microbiological study

The raw drug for the preparation of twak arka and triphala kwatha were ordered and procured from $\mathrm{C}$ K Kumaran Memorial (CKKM) Pharmacy, Tripunithura, Kerala and authentication was also done from the same. 


\section{Preparation of twak arka (5)}

The preparation of twak arka was done under aseptic conditions by following the ratio of 1:3 (drug: water) and volume/ volume (v/v) measurement. Dried drug of the specified species was cleaned, coarsely powdered (sieve number 44) and used for arka preparation. Initially the mentioned quantity of coarse powder of twak was taken in a round bottom flask and soaked with sufficient quantity of water just enough to soak the drug $(200 \mathrm{ml})$ and kept overnight. Next day morning, remaining quantity of water $(100 \mathrm{ml})$ was added and the Arka yantra (distillation apparatus) was set and heating was started. The heat given was $60^{\circ}$ initially; once it started boiling temperature gradient was maintained between $40^{\circ}-60^{\circ}$ during the procedure. Initial few drops of twak arka were discarded as it may not contain therapeutically essential substances and the process of distillation of twak arka was continued till $30 \%$ of the distillate was collected.

\section{Preparation of triphala kwatha}

One part of kwatha churna of triphala [amalaki (Emblica officinalis Gaertn), haritaki (Terminalia chebula Retz) and vibhitaki (Terminalia bellerica Roxb)] were taken in a clean sterile stainless steel vessel and added with four parts of water, kept for boiling. Study follows 1:4 (drug: water) weight/ volume $(\mathrm{w} / \mathrm{v})$ measurement for the preparation and when $k$ watha reduced to $1 / 4^{\text {th }}$, it was filtered through a clean cloth.

\section{Preparation of sample}

To the $50 \mathrm{ml}$ of triphala kwatha, $7.5 \mathrm{ml}$ of twak arka was added in the concentration of $15 \%$ based on the previous research study (6).

\section{Analytical study}

Analytical study includes organoleptic and physico- chemical parameters of twak arka and triphala kwatha. Also $\mathrm{pH}$ of sample was done on the day of preparation and on the day of spoilage. Analysis of the following parameters was done based on the references available in the CCRAS protocol (7).

1. Morphological evaluation- organoleptic charactersappearance, color, odor, taste

2. Physico- chemical parameters- $\mathrm{pH}$, Specific gravity, viscosity, total suspended solids, refractive index, volatile oil estimation

The above mentioned analytical parameters were carried out for three times and the average reading or value was taken as a result.

\section{Preparation of media (8)}

For this study, Sabouraud Dextrose Agar (SDA) medium, Mueller Hinton Agar (MHA) medium were used to see the fungal and bacterial growth respectively.

\section{Microbiological study}

The study was carried out in the Microbiology Laboratory of the department of Roganidana evam Vikriti Vigyana, Sri Dharmasthala Manjunatheshwara College of Ayurveda \& Hospital, Hassan. Every day new plates were used from both the media and were done in aseptic precautions for better result. To test the microbial contamination, streaking method was adopted on both media (SDA and MHA) using inoculum loop and plates were kept overnight with respective temperature to assess the growth on the next day. Microscopic view of the sample was checked on the day of microbial growth.

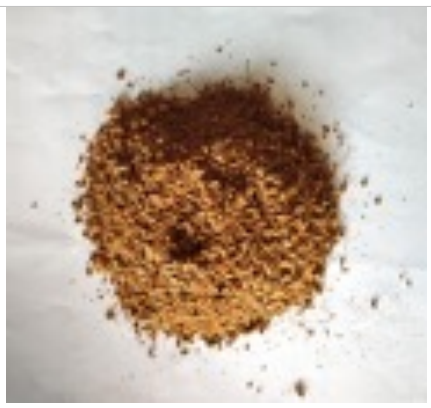

Fig 1(a): Twak coarse powder

Fig 1(a to c): Preparation of Twak arka



Fig 1(b): Distillation process

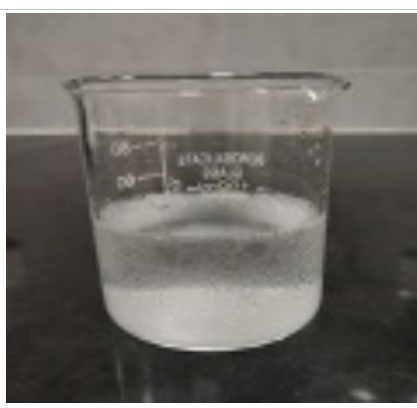

Fig 1(c): Twak arka

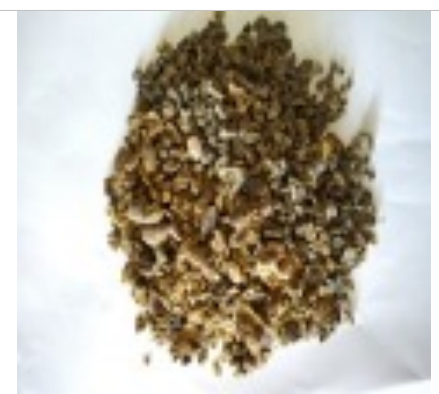

Fig 2(a): Triphala kwatha churna

Fig 2 (a to c): Preparation of Triphala kwatha

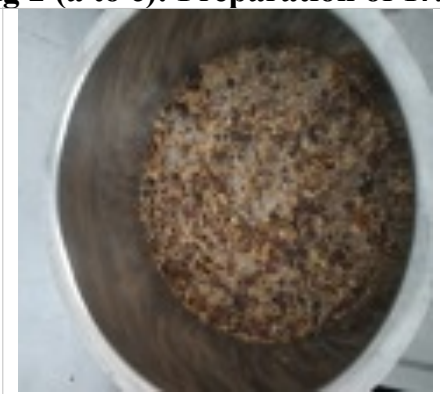

Fig 2(b): Process of boiling

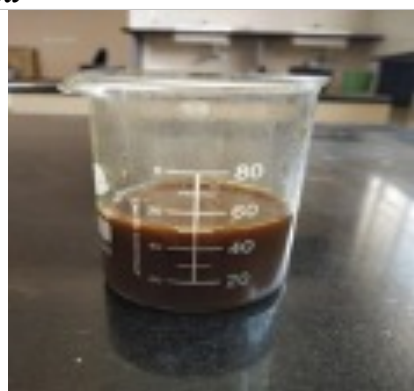

Fig 2(c): Triphala kwatha 
Fig 3: Preparation of sample

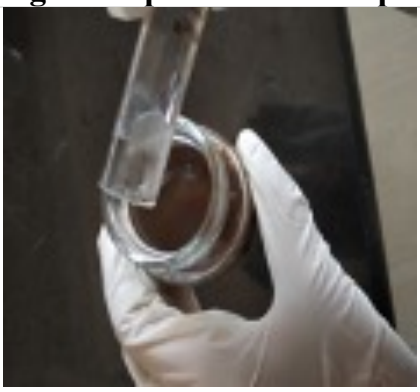

Fig 4: Preparation of media

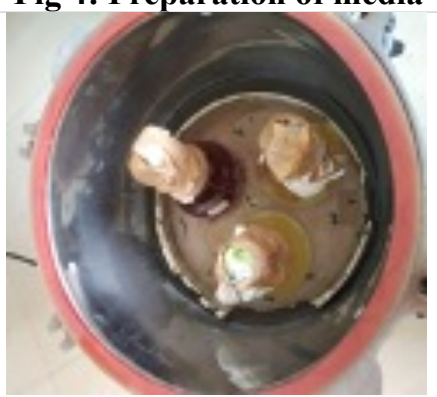

Fig 5: Streaking of sample on plate

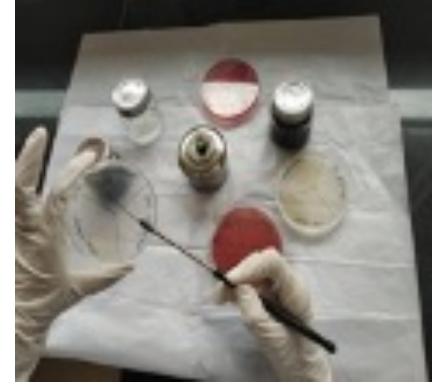

Fig 6: 24 to 48 hours- no growth in SDA media



Fig 7: 32nd day- growth


Fig 8: Microscopic view

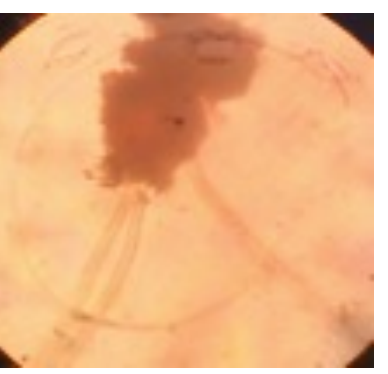

\section{Observations and Results}

Table 1: Observations during preparation of Twak arka

Drug quantity (v/v)

\section{Parameters}

Water

Proportion (drug: water)

Initial temperature

Maintained temperature gradient

Starting time

Time of first drop

Ending time

Distillate obtained

$\%$ obtained
Twak arka 100ml (48.15g) $300 \mathrm{ml}$

$1: 3$

$$
60^{0}
$$

$40^{0}-60^{0}$

9:40am

10:05am

$1: 15 \mathrm{pm}$ $90 \mathrm{ml}$

$30 \%$

Obtained twak arka was colorless liquid with an aromatic characteristic odor and had a layer of volatile content above and below the surface possessed madhura (sweet) rasa (taste) with strong tingling sensation on taste.

Table 2: Observations during preparation of triphala kwatha

\section{Drugs used}

Proportion (drug: water)

Quantity of drugs

Quantity of water

Reduction

Temperature (degree Celsius)

Triphala kwatha obtained was brown liquid possessed characteristic odor, tikta (bitter) rasa pradhana kashaya (astringent) rasa on taste.

Table 3: Analytical parameters of twak arka and triphala kwatha

\begin{tabular}{|r|l|l|l|}
\hline Sl. No. & Particulars & Twak arka & Triphala kwatha \\
\hline $\mathbf{1}$ & Appearance & $\begin{array}{l}\text { Liquid with a layer of volatile } \\
\text { content above and below the surface }\end{array}$ & Brown liquid \\
\hline $\mathbf{2}$ & Color & Colorless liquid & Brown \\
\hline $\mathbf{3}$ & Odor & Aromatic characteristic odor & Characteristic odor \\
\hline $\mathbf{4}$ & Taste & $\begin{array}{l}\text { Madhura rasa pradhana with strong } \\
\text { tingling sensation }\end{array}$ & $\begin{array}{l}\text { Tikta rasa pradhana kashaya } \\
\text { rasa }\end{array}$ \\
\hline $\mathbf{5}$ & pH & 3.15 & 3.14 \\
\hline $\mathbf{6}$ & Specific gravity & 0.9990 & 1.0608 \\
\hline $\mathbf{7}$ & Viscosity (Pa.s) & 0.0059 & 0.0137 \\
\hline $\mathbf{8}$ & TSS (Total Suspended Solids) $\mathbf{m g} / \mathbf{l}$ & 0.1 & 17 \\
\hline $\mathbf{9}$ & Refractive index & 1.34 & 1.36 \\
\hline $\mathbf{1 0}$ & Volatile oil estimation $\mathbf{( \% )}$ & $0.08 \%$ & - \\
\hline
\end{tabular}
$1: 4(\mathrm{w} / \mathrm{v})$ $360 \mathrm{~g}(120 \mathrm{~g}$ each $)$ $1440 \mathrm{ml}$$$
1 / 4^{\text {th }}
$$$$
88^{0}-95^{\circ} \mathrm{C}
$$

Amalaki, haritaki, vibhitaki kwatha churna 


\section{Microbiological study}

The study was conducted by storing the sample in sterile autoclaved glass bottle in normal room temperature. Two media were used includes SDA and MHA to see the growth of fungus and bacteria respectively by adopting streaking method using petri dish. After streaking in the plates by adopting aseptic precautions, SDA plates were kept in normal room temperature between $30^{0}-35^{\circ}$ Celsius for 24- 48 hours to observe the growth; MHA plates were kept in incubator by maintaining the temperature between $35^{0}-41^{0}$ Celsius for 24 hours to see the growth for the study.

\section{Table 4: Observations and results during microbiological study}

\begin{tabular}{|c|c|c|c|c|c|c|c|}
\hline \multirow{2}{*}{ Sample } & \multirow{2}{*}{$\begin{array}{c}\text { Date of } \\
\text { preparation }\end{array}$} & \multirow{2}{*}{$\begin{array}{c}\text { Date of } \\
\text { spoilage }\end{array}$} & \multirow{2}{*}{$\begin{array}{l}\text { Number of } \\
\text { days stayed }\end{array}$} & \multicolumn{2}{|c|}{ SDA medium } & \multicolumn{2}{|c|}{ MHA medium } \\
\hline & & & & Growth date & Organism & Growth date & Organism \\
\hline $\begin{array}{l}\text { Twak arka in } \\
\text { triphala } \\
\text { kwatha added } \\
\text { in } 15 \%\end{array}$ & $\begin{array}{l}\text { 8/10/2020 } \\
(\mathrm{pH}: 2.88)\end{array}$ & $\begin{array}{l}\text { 9/11/2020 } \\
\text { (pH: } 2.12)\end{array}$ & 31 days & $9 / 11 / 20$ & $\begin{array}{c}\text { Aspergillus } \\
\text { niger }\end{array}$ & No growth & No growth \\
\hline
\end{tabular}

The microbial load was assessed by assessing the growth over the media plates and microscopic view of the sample was done. In the microscopic view, motile microbes suggestive of contamination were observed. Aspergillus niger was the fungus found when viewed under microscope. It is one of the most common species of the genus Aspergillus belongs to Trichocomaceae family (9). It is known usually to cause food contaminations or food spoilage. No growth was observed in the plates of MHA media.

\section{Discussion}

Twak possesses different properties which have positive result for the study like anti- microbial and anti- oxidant properties. In classical Ayurveda treatises also many references are available that explains the gunaadi karma of drug twak. Owing to these properties, this study was taken up to assess the extent or days of preservative action of twak drug in its arka form by extracting volatile content to check the probable preservative action in triphala kwatha.

Twak arka was prepared by taking 1:3 ratio of drug and water considering v/v measurement. During preparation, size reduction of drug was done by making coarse powder of the drug which helps to increase the surface area of the drug for the active principles to be dissociated into water. So soaking was done overnight to make the drug soft and this helps in release of essential volatile principles while boiling as the drug twak is rich in volatile content. Next day distillation process was started by adding remaining amount of water. As the amount of water used for the preparation was less, precaution has to be taken not to char the drug and not to collect the distillate more than the calculated quantity as it may not contain therapeutically potent or essential substances. Arka obtained finally was a colorless liquid possessed characteristic aromatic odor with a layer of volatile content and had madhura rasa in predominance with more tingling sensation was appreciated because of the higher concentration of constituents present in the drug.

Yavakuta churna (coarse powder) used for the preparation of triphala kwatha facilitates the proper absorption of water soluble principles followed 1:4 ratio of drug and water and reduced to $1 / 4^{\text {th }}$ of the total volume. Triphala kwatha obtained was brown in color, possessed characteristic odor with tikta pradhana kashaya rasa.

Twak arka had $\mathrm{pH}$ of 3.15 suggestive of highly acidic nature where more acidic nature also act as preservative and the efficacy, absorption, irritability also depends on $\mathrm{pH}$ of a drug. A more acidic $\mathrm{pH}$ result in lesser oxidation suggestive of acidic nature reduces the growth of micro-organisms (10). Triphala kwatha had $\mathrm{pH}$ of 3.14, which was also acidic in nature; this also influences on the rate of oxidation. Specific gravity of twak arka and also the triphala kwatha was near to the value one suggestive of these had specific gravity that was similar to water. Viscosity of twak arka was similar to that of water as it is a distillate of water. Viscosity of triphala kwatha was 0.0137 as it was a filtrate of water along with drugs. Total suspended solids for arka was $0.1 \mathrm{mg} / 1$ as it was a distillate it would only have water soluble active principles along with volatile principles extracted from the raw drug. But the total suspended solids of triphala kwatha was17 suggestive of more solid particles suspended in the final filtrate liquid. Refractive index of both arka and kwatha suggests that they had low viscosity and density. Twak arka contained volatile matters in the form of essential oil.

Microbiological study was conducted to test the microbial contamination of the sample and to check the number of days of preservative action of twak arka in triphala kwatha. Arka showed preservative action for 31 days without any microbial contamination. The drug is a rich source of essential oil; this could have also impacted on the reduction and the components present in twak arka could have also influenced over the rate of microbial growth and twak arka was highly acidic in nature this could have reduce the rate of oxidation as the acidic nature helps in reducing the growth of microbes.

\section{Conclusion}

By this study it was concluded that the twak arka showed preservative action for 31 days in triphala $k$ watha without any microbial contamination owing to its properties which was added in the concentration of $15 \%$. Aspergillus niger was the fungal growth observed which is a common food spoilage organism is the most common species of the genus Aspergillus. This study 
extends scope for many research works to be taken up on the same path.

\section{Acknowledgement}

I am very much thankful to Dr Shashirekha K S, Microbiologist at Department of Roganidana evam Vikriti Vigyana at SDM College of Ayurveda and Hospital, Hassan for her crucial guidance in preparing this research article. Also I thank staff members of C K Kumaran Memorial (CKKM) Pharmacy, Tripunithura, Kerala for drug authentication.

\section{References}

1. Acharya Sharangadhara, Shastry P. Sharangadhara Samhita with Deepika and Gudarthadipika commentary. 7th ed. Varanasi: Chaukhambha Orientalia; 2002. p. 145.

2. Aledwany A Z, Basal W T, Al-Senosy N K, Issa A M. Evaluation of the Cytotoxicity, Cell Cycle Perturbations and Apoptotic Induction in Human Normal and Cancer Liver Cell Lines Exposed to Potassium Nitrate and Sodium Benzoate. Egyptian Academic Journal of Biological Sciences, B. Zoology. 2018 Jun 1; 10(1): p. 105-18.https:// eajbsz.journals.ekb.eg/article_26985.html

3. Rakshitha D, Hussain Gazala. Preliminary pharmaceutico analytical study of Trisugandha arka. IJAAR. 2020; 4(11): p. 1331-36. http:// w w w. i ja a r.in/i m a g e s / u p lo a d / IJAAR_VOLUME_IV_ISSUE_XI_ NOV $\%$ E $2 \%$ 80\%93̄̄EC 2020_Page_No_1331_ 1336.pdf

4. Rakshitha D, Balagopalan Devika, Hussain Gazala. A Review on Chaturjataka. IJRAR. 2020; 7(4): p.
510-19. https://www.researchgate.net/publication/ 345306874_A_Review_On_Chaturjataka

5. Government of India Ministry of Health \& Family Welfare. The Ayurvedic Formulary of India. Second edition. New Delhi. The Controller of Publications Civil Lines, Delhi: Part I. p. 27.

6. Devika Balagopalan. Pharmaceutico Analytical Evaluation of Chaturjataka Arka as a preservative for Triphala Kashaya. Sri Dharmasthala Manjunatheshwara College of Ayurveda and Hospital, Hassan. 2019. p. 25.

7. CCRAS. Laboratory Guide for the Analysis of Ayurveda and Siddha Formulations. First edition. New Delhi. CCRAS Department of AYUSH, Ministry of Health and Family Welfare; 2009.

8. Pooja B. Modification of Kasisadi Churna to Varti, its physico chemical analysis and invitro study against Candida albicans. Sri Dharmasthala Manjunatheshwara College of Ayurveda and Hospital, Hassan. 2020. P. 73.

9. Schuster E, Dunn-Coleman N, Frisvad J C, Van Dijck P W. On the safety of Aspergillus niger- a review. Applied microbiology and biotechnology. 2002 Jan; 59(4): p. 426-35.https:// pubmed.ncbi.nlm.nih.gov/12172605/

10. Oladipo I C, Adeleke D T, Adebiyi A O. The effect of $\mathrm{pH}$ and chemical preservatives on the growth of bacterial isolates from some Nigerian packaged fruit juices. Pakistan journal of biological sciences: PJBS. 2010 Jan 1; 13(1): p. 16-21. https:// scialert.net/abstract/?doi=pjbs.2010.16.21 